\title{
POTENSI DAN PEMANFAATAN TANAMAN BAMBU PADA LAHAN MASYARAKAT DI DESA KADING KABUPATEN BARRU
}

\author{
Potency and Utilization of Community Bamboo Plantations in the Kading Village of Barru District \\ Miftahul Jannah ${ }^{1 凶}$, Baharuddin, Ira Taskirawati ${ }^{3}$ \\ 1Mahasiswa Program S1 Kehutanan, Fakultas Kehutanan, Universitas Hasanuddin, Makassar \\ 2Dosen Pengajar Fakultas Kehutanan, Universitas Hasanuddin, Makassar \\ ${ }^{\otimes}$ corresponding author: miftahuljannahh24@gmail.com
}

\begin{abstract}
Non-wood forest products (NTFPs) are the result of the forestry sector those are still very much needed by the world and can be an opportunity to add value to the economy, especially in the forestry sector. This study aims to determine the potential and utilization of bamboo on community land in Kading Village, Tanete Riaja District, Barru Regency. There are two data collected in this study; they are potential data and bamboo plant utilization data. Potential data collection in this study was carried out in three stages, namely mapping the distribution point of a bamboo clump, collecting data on an area of farmer's garden that has bamboo, and counting the number of bamboo groves on the respondent's bamboo land. Candid interviews with 30 bamboo landowners obtained the data on the use of bamboo plants. The total area of community land covered with bamboo in Kading Village is 7.29 ha with 250 clumps consisting of 2,203 bamboo shoots, 5,345 young bamboo, and 4,532 old bamboos.
\end{abstract}

Key words: NTFPs, Bamboo Potential, Utilization.

\section{A. PENDAHULUAN}

Hasil sektor kehutanan masih sangat dibutuhkan oleh dunia. Selain dari sumbangsi jasa seperti tata air dan penghasil oksigen, hutan juga menghasilkan hasil hutan bukan kayu (HHBK) berupa rotan, nilam, bambu, palem, sagu, getah dan aren. Besarnya potensi pemanfaatan HHBK tersebut menjadi peluang dalam menambah nilai ekonomi khususnya di sektor kehutanan. Priyanto \& Abdulah (2014) menyatakan salah satu hasil hutan yang banyak ditemukan di Indonesia adalah bambu.

Bagian Timur Indonesia menjadi tempat potensial untuk bambu tumbuh dan berkembang. Sulawesi menjadi salah satu daerah penghasil bambu terbesar di Indonesia, juga menjadi tempat berbagai jenis bambu. Terdapat sekitar 140 jenis bambu di Indonesia (Lempang, 2016). Hingmadi (2012) memperkirakan 88 jenis bambu adalah endemik Indonesia. Banyaknya jenis bambu membuat pemanfaatan bambu juga semakin variatif. Menurut Priyanto \& Abdulah (2014) pada tahun 2014 luas hutan bambu Indonesia mencapai 2.058.000 ha.

Kabupaten Barru tepatnya di Desa Kading juga memiliki potensi bambu namun belum diketahui potensi secara kuantitatif. Masyarakat Desa Kading juga telah lama memanfaatkan bambu, terutama sebagai bahan baku utama untuk pembuatan rumah. Namun, masyarakat Desa Kading belum mampu memvariasikan produk-produk bambu yang bernilai tinggi di pasaran. Hal ini dikarenakan kurangnya informasi dalam pengolahan bambu serta tidak adanya penyuluhan yang pernah dilakukan tentang potensi dan pemanfaatan bambu itu sendiri. Berdasarkan hal tersebut diatas perlu digali lebih dalam mengenai potensi dan pemanfaatan yang luas guna meningkatkan kesadaran masyarakat untuk melestarikan tanaman ini. Oleh karena itu, penelitian ini dilakukan untuk mengetahui data potensi tanaman bambu dan pemanfaatan bambu yang ada di Desa Kading.

\section{B. METODE PENELITIAN}

Populasi dalam penelitian ini yaitu masyarakat di Desa Kading, Kecamatan Tanete Riaja, Kabupaten Barru. Pada penelitian ini dilakukan pengambilan titik sampling dengan cara purposive sampling yaitu sampel ditentukan secara sengaja, dengan cara observasi lapangan dan wawancara langsung yang memiliki tanaman bambu di lahan kebun yaitu 30 titik lahan masyarakat (Gambar 1.).

\section{Pengumpulan Data Potensi}

Metode pengumpulan data potensi dilakukan dengan cara:

1. Pembuatan peta titik penyebaran rumpun di Desa Kading, guna mengetahui berapa jumlah rumpun yang 
ada pada luas areal Desa Kading, Kecamatan Tanete Riaja, Kabupaten Barru.

2. Melakukan pengumpulan data luas lahan kebun petani yang memiliki bambu, dengan menggunakan kuesioner. Kuesioner tersebut memuat nama responden, umur; jenis kelamin, pekerjaan, jumlah pendapatan, pendidikan terakhir, luas lahan, status lahan, jenis bambu, pemanfaatan dan harga bambu.

3. Menghitung jumlah rumpun bambu pada lahan bambu responden serta menghitung jumlah rebung, jumlah bambu muda dan bambu tua pada setiap rumpun bambu.

\section{Pengumpulan Data Pemanfaatan Tanaman Bambu}

Pengambilan dan pemanfaatan tanaman bambu dilakukan dengan cara wawancara langsung terhadap 30 pemilik lahan bambu dengan menggunakan daftar pertanyaan dan pertanyaan bebas.

\section{Analisis Data}

Potensi rata-rata batang per rumpun, rata-rata rumpun per lahan masyarakat, dan rata-rata jumlah rumpun per hektar masing-masing diduga dengan persamaan (1), (2) dan (3).
$\overline{X B R}=\frac{\sum r+\sum B m+\sum B t}{\sum R B}$

Keterangan: $\overline{X B R}$ adalah rata-rata batang bambu per rumpun; $\sum r$ adalah jumlah bambu rebung; $\sum B m$ adalah Jumlah bambu bambu muda; $\sum B t$ adalah Jumlah bambu bambu tua; dan $\sum R B$ adalah total jumlah rumpun bambu lahan masyarakat.

$\overline{X B L}=\frac{\sum R B}{\sum R S}$

Keterangan: $\overline{X B L}$ adalah rata-rata rumpun bambu per lahan masyarakat; $\sum R B$ adalah jumlah rumpun bambu setiap kelas lahan; dan $\sum R S$ adalah jumlah pemilik lahan bambu di setiap kelas lahan.

$\bar{X}=\frac{\sum R}{\text { Luas }_{t}}$

Keterangan: $\bar{X}$ adalah rata-rata jumlah rumpun per ha; $\sum R$ adalah total jumlah rumpun bambu lahan masyarakat; dan Luas $_{t}$ adalah luas total lahan masyarakat.

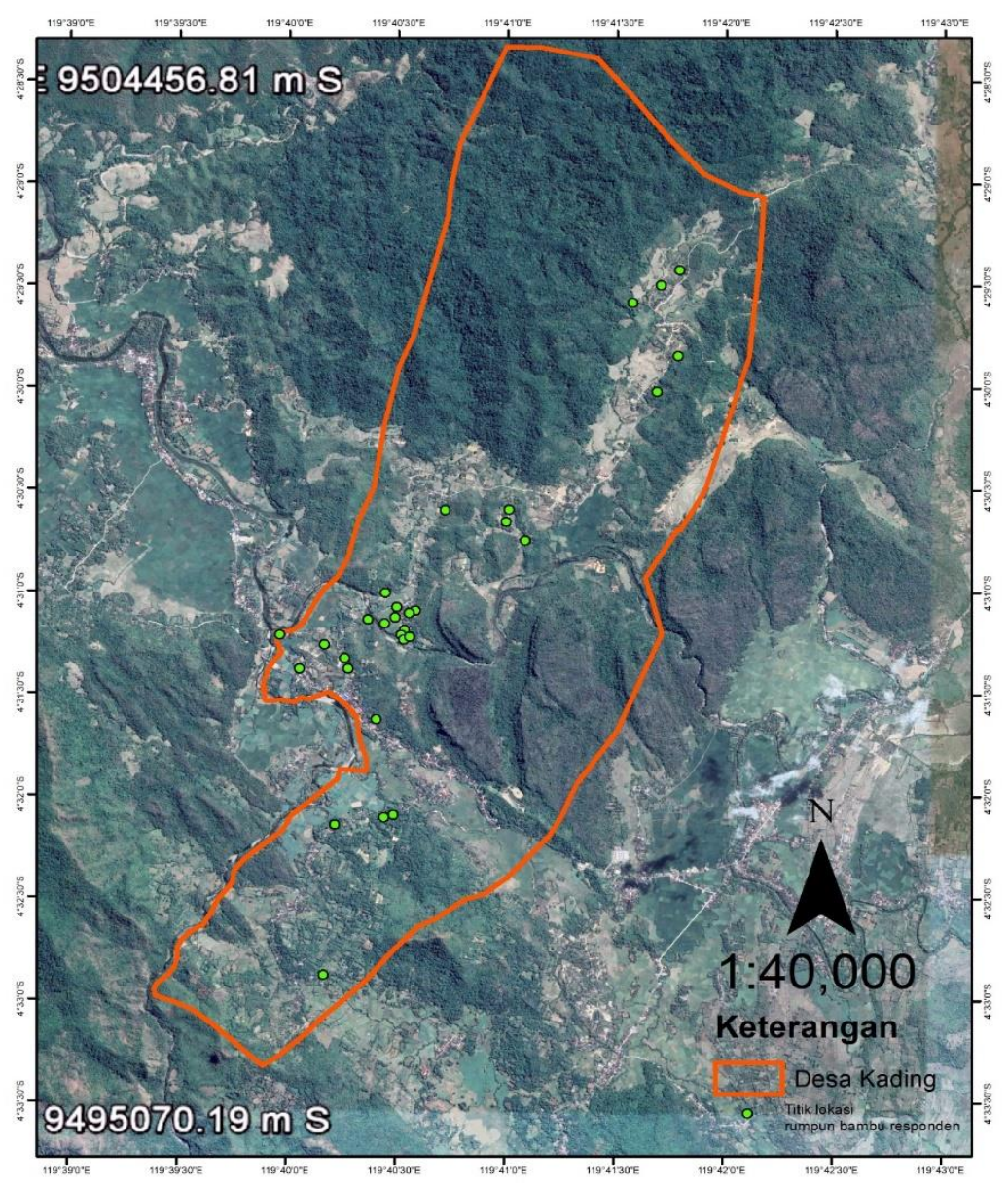

Gambar 1. Peta Titik Penyebaran Bambu di Desa Kading, Kabupaten Barru. 


\section{HASIL DAN PEMBAHASAN}

\section{Letak dan Luas Wilayah Penelitian}

Desa Kading adalah salah satu desa yang berada di Kecamatan Tanete Riaja, Kabupaten Barru, dengan total luas wilayah 226,9 ha. Desa Kading terdiri atas lima Dusun yaitu Dusun Bunne, Dusun Rumpiae, Dusun Pasar baru, Dusun Umpungnge dan Dusun Tokkene. Keadaan topografi umumnya berbukit, hanya sebagian kecil yang berombak, secara umum berada pada tipe ekosistem datar dengan ketinggian di bawah $500 \mathrm{~m}$ di atas permukaan laut (dpl).

Berdasarkan letak dalam wilayah DAS Desa Kading, Kecamatan Tanete Riaja dialiri sungai WAE SAID dengan panjang secara keseluruhan $24 \mathrm{~km}$ dengan ketinggian $4 \mathrm{~m}$ dan dengan kedalaman $2,5 \mathrm{~m}$ dengan sumber air tersebut dapat berpeluang menunjang pertumbuhan bambu di Desa Kading, Kecamatan Tanete Riaja, serta memiliki jenis tanah alluvial (BPS, 2017). Jarak Desa Kading dari Ibu Kota Kabupaten Barru adalah 20 km. Desa Kading dapat dicapai dengan menggunakan kendaraan roda dua maupun kendaraan roda empat dengan waktu tempuh \pm 4 jam dari Kota Makassar.

\section{Tingkat Pendidikan Petani Bambu Pada Lahan Masyarkat di Desa Kading}

Tingkat pendidikan responden yang ada di Desa Kading masih sangat rendah, hal ini disebabkan karena masih kurangnya tingkat kesadaran akan pentingnya pendidikan. Berdasarkan pengambilan data responden pemilik bambu di Desa Kading, yang tidak bersekolah sebanyak 5 orang (17\%), sekolah buta huruf sebanyak 2 orang (7\%), SD sebanyak 11 orang (37\%), SMP sebanyak 2 orang (7\%), SMA sebanyak 7 orang (23\%), Sarjana sebanyak 3 orang (10\%), Tingkat pendidikan responden petani bambu di Desa Kading dapat dilihat pada Tabel 1.
Tabel 1. Karakteristik berdasarkan tingkat pendidikan

\begin{tabular}{cccc}
\hline No & $\begin{array}{c}\text { Tingkat } \\
\text { Pendidikan }\end{array}$ & Responden & $\begin{array}{c}\text { Persentase } \\
(\%)\end{array}$ \\
\hline 1 & Tidak Sekolah & 5 & $17 \%$ \\
2 & Buta Huruf & 2 & $7 \%$ \\
3 & SD & 11 & $37 \%$ \\
4 & SMP & 2 & $7 \%$ \\
5 & SMA & 7 & $23 \%$ \\
6 & Sarjana & 3 & $10 \%$ \\
\hline
\end{tabular}

\section{Tingkat Umur Pada Lahan Masyarakat di Desa Kading}

Salah satu faktor yang mempunyai pengaruh terhadap produktivitas seseorang dalam bekerja adalah faktor usia. Pertumbuhan penduduk usia muda (0-15 tahun), usia sangat produktif (15-64 tahun). Usia yang masih produktif biasanya mempunyai tingkat produktivitas lebih tinggi, karena muda dan sehat jasmaninya masih memiliki kemampuan fisik yang lebih kuat dan inovatif. Dibandingkan dengan tenaga kerja yang sudah berusia tua, fisik yang dimiliki menjadi lemah dan terbatas. (Mahendra, 2014; Tanto, Dewi, \& Budio, 2012).

Tabel 2. Karakteristik berdasarkan kelompok umur

\begin{tabular}{clcc}
\hline No & \multicolumn{1}{c}{ Kelompok Umur } & Responden & $\begin{array}{c}\text { Persentase } \\
(\%)\end{array}$ \\
\hline 1 & $\begin{array}{l}\text { Belum Produktif }(<15 \\
\text { Tahun }\end{array}$ & 0 & 0 \\
2 & $\begin{array}{l}\text { Produktif }(15-64 \\
\text { Tahun ) }\end{array}$ & 22 & $73 \%$ \\
3 & Tidak Produktif $(>64)$ & 8 & $27 \%$ \\
\hline
\end{tabular}

Table 2. menunjukkan bahwa persentase responden bambu di Desa Kading dengan kelompok umur produktif adalah sebesar $73 \%$, sedangkan responden bambu yang sudah tidak produktif yaitu sebesar $27 \%$. Hal ini menunjukkan bahwa usia responden bambu yang ada di Desa Kading masih mampu untuk bekerja dan mengolah tanaman bambu atau usaha lainnya.
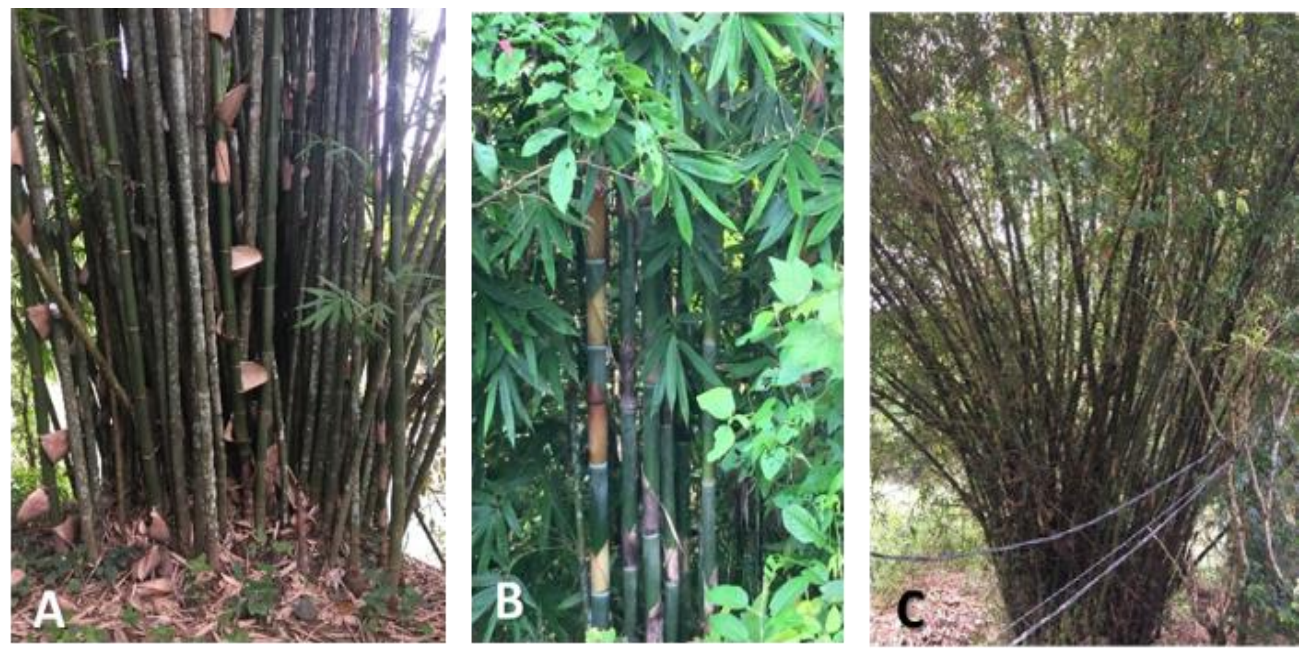

Gambar 2. Tiga jenis bambu yang ada pada lahan masyarakat di Desa Kading, Kabupaten Barru: a). Gigantochloa atter, b). Schizostachyum brachycladum, dan c). Bambusa vulgaris. 


\section{Jenis-jenis Tanaman Bambu Pada Lahan Masyarakat}

Terdapat tiga jenis bambu yang ada di Desa Kading yang diperoleh dari hasil observasi langsung dilapangan yaitu bambu jenis Gigantochloa atter, Schizostachyum brachycladum, dan Bambusa vulgaris (Gambar 2.). Selain tumbuh di lahan petani, bambu G. atter juga banyak ditemui di tepi-tepi jalan desa. Bambu $S$. brachycladum juga banyak di pinggiran jalan desa, dan daerah dataran tinggi. Sedangkan bambu jenis Bambusa vulgaris, banyak ditemui dipinggiran sungai.

Hasil inventarisasi jumlah rumpun bambu yang ada di Desa Kading, Barru ditunjukkan pada Tabel 3. Pada Tabel 3 terlihat bahwa jenis bambu yang tumbuh mendominasi lahan milik petani adalah bambu $G$. atter.

Table 3. Jenis-jenis bambu yang terdapat pada lahan masyarakat di Desa Kading

\begin{tabular}{clc}
\hline No & \multicolumn{1}{c}{ Jenis bambu } & Jumlah rumpun \\
\hline 1. & Bambu Gigantochloa atter & 219 \\
2. & $\begin{array}{l}\text { Bambu Schizostachyum } \\
\text { brachycladum }\end{array}$ & 14 \\
3. & Bambu Bambusa vulgaris & 17 \\
\hline
\end{tabular}

Tabel 4. Potensi rata-rata bambu per rumpun

\begin{tabular}{cccc}
\hline No & Tingkatan pertumbuhan bambu & Jumlah & Rata-rata \\
\hline 1 & Rebung & 2.203 & 9 \\
2 & Bambu Muda & 5.345 & 21 \\
3 & Bambu Tua & 4.532 & 18 \\
\hline & Total & 12.080 & 48 \\
\hline
\end{tabular}

\section{Potensi Tanaman Bambu}

Inventarisasi bambu Desa Kading, Kecamatan Tanete Riaja, Kabupaten Barru dilakukan pada areal dengan luas wilayah 226,9 ha. Tanaman bambu memiliki 99 titik penyebaran rumpun bambu dengan total jumlah rumpun sebanyak 541 rumpun. Akan tetapi, lahan masyarakat di Desa kading yang ditanami bambu, diperoleh sebanyak 30 titik dengan jumlah rumpun 250 rumpun bambu.

Tabel 4 menunjukkan pada tingkat pertumbuhan rebung terdapat sebanyak 2.203 buah, didominasi oleh rebung jenis $\mathrm{G}$. atter, bambu muda 5.345 batang, dan bambu tua 4.532 batang juga didominasi oleh jenis bambu G. atter dan diperoleh total jumlah batang yaitu 12.080 . Sehingga, jika dirata-ratakan maka setiap rumpun bambu akan terdiri atas 9 buah rebung, 21 batang bambu tua, dan 18 batang bambu muda dengan total rata-rata 48 batang setiap rumpunnya.

Hamim, Zaidon, Abdood, \& Anwar (2010) menyatakan bahwa pada setiap rumpun bambu terdapat 40-50 batang dan bertambah lebih dari 10-20 batang setiap tahun. Sutardi et al., (2015) menjelaskan secara umum bambu $G$. atter dari masing-masing rumpun memiliki jumlah batang bambu dapat mencapai 35-45 batang. Dari kedua pernyataan tersebut, maka bambu yang tumbuh di Desa Kading masih masuk dalam kisaran pertumbuhan bambu yang normal.

Tabel 4. juga menunjukkan bahwa pertumbuhan rebung dan bambu muda, sebanding dengan pertumbuhan bambu tua. Artinya, dalam satu rumpun bambu terdapat regenerasi yang baik dimana rebung, bambu muda dan bambu tua tumbuh dengan rasio yang seimbang. Sehingga kedepannya, potensi bambu di Desa ini masih bisa terus berkembang dan lestari.

\section{Potensi Rumpun Bambu Pada Lahan Masyarakat di Desa Kading}

Potensi tegakan bambu di Provinsi Sulawesi Selatan rata-rata sebanyak 4.635 batang per ha dengan jumlah rumpun 190 per ha (Daud, Achmad, Faisal, \& Baharuddin, 2016). Potensi tegakan rumpun bambu di Desa Kading disajikan pada Tabel 5 .

Lahan masyarakat dibagi berdasarkan tiga tingkatan luas areal lahan yang ditanami bambu oleh Petani. Jumlah rumpun bambu paling banyak ditemui pada lahan dengan luasan antara 0,29-0,36 ha (101 rumpun). Pada luasan ini, setiap petani, rata-rata memiliki rumpun bambu sebanyak 10 rumpun dan rata-rata jumlah bambu sebanyak 48, dengan rincian 98 rebung, 172 bambu muda dan 219 bambu tua. Jumlah rumpun terbanyak kedua adalah lahan dengan luasan antara $0,13-0,20$ ha (77 rumpun). Pada luasan ini, setiap petani, rata-rata hanya memiliki rumpun bambu sebanyak 6 rumpun dan rata-rata jumlah bambu sebanyak 49 , dengan rincian 57 rebung, 114 bambu muda dan 123 bambu tua.

Tabel 5. Potensi rumpun bambu pada lahan masyarakat di Desa Kading.

\begin{tabular}{|c|c|c|c|c|c|c|c|c|}
\hline \multirow[b]{2}{*}{ No. } & \multirow[b]{2}{*}{$\begin{array}{l}\text { Luas Lahan } \\
\text { (ha) }\end{array}$} & \multirow[b]{2}{*}{$\begin{array}{c}\text { Jumlah } \\
\text { Responden }\end{array}$} & \multirow[b]{2}{*}{$\begin{array}{l}\text { Jumlah } \\
\text { Rumpun }\end{array}$} & \multicolumn{4}{|c|}{ Rata-Rata bambu per Lahan masyarakat } & \multirow{2}{*}{$\begin{array}{c}\text { Rata-ratc } \\
\text { bambu }\end{array}$} \\
\hline & & & & Rumpun & Rebung & $\begin{array}{l}\text { Bambu } \\
\text { Muda }\end{array}$ & $\begin{array}{c}\text { Bambu } \\
\text { Tua }\end{array}$ & \\
\hline 1 & $0,13-0,20$ & 12 & 77 & 6 & 57 & 114 & 123 & 49 \\
\hline 2 & $0,21-0,28$ & 8 & 72 & 9 & 67 & 181 & 211 & 51 \\
\hline \multirow[t]{2}{*}{3} & $0,29-0,36$ & 10 & 101 & 10 & 98 & 172 & 219 & 48 \\
\hline & Jumlah & 30 & 250 & 25 & 222 & 467 & 553 & 48 \\
\hline
\end{tabular}


Table 6. Produk dari Bambu yang Dikonsumsi dan Dijual oleh Responden di Desa Kading.

\begin{tabular}{ccccc}
\hline No & Jenis pemanfaatan & Jumlah kebutuhan bambu & $\begin{array}{c}\text { Tingkatan pertumbuhan bambu } \\
\text { yang digunakan }\end{array}$ & Harga jual per unit (Rp.) \\
\hline 1 & Batang Bambu & per batang & bambu tua & $4.000-10.000$ \\
2 & Pagar & $\begin{array}{c}5 \text { batang } \\
\text { bambu tua }\end{array}$ & - \\
3 & Lemang & $\begin{array}{c}\text { 1 bambu talang dibagi } \\
\text { menjadi } 2-6 \text { potong }\end{array}$ & bambu talang muda & $25.000-35.000$ \\
& & Besar 2 batang & bambu tua & $25.000-35.000$ \\
4 & Kurungan Ayam & Kecil 1 batang & bambu tua & 20.000 \\
5 & Baki Ayam & 1 batang & bambu tua & 35.000 \\
6 & Bubu lkan & 2 batang & bambu tua & - \\
8 & Dinding & $4-6$ batang & bambu tua & - \\
\hline
\end{tabular}
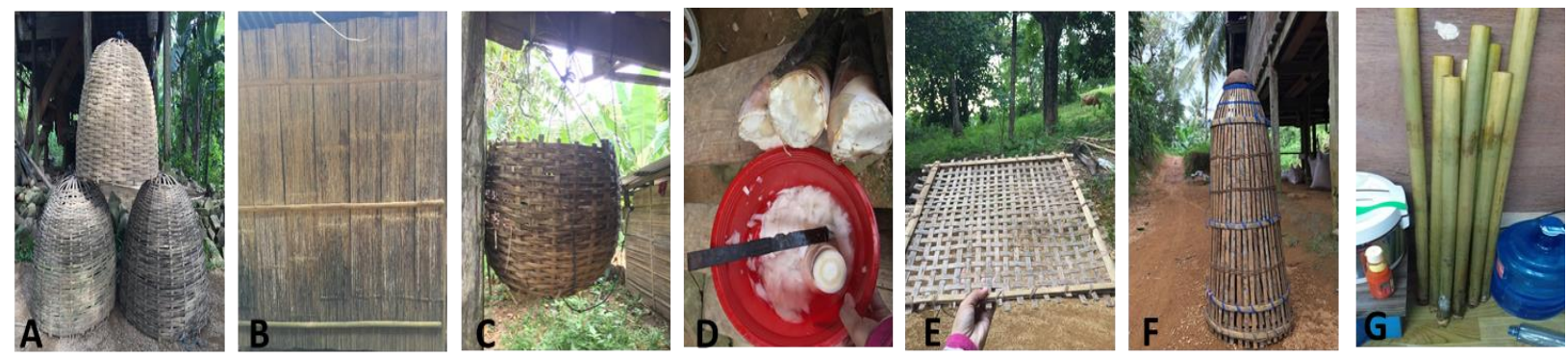

Gambar 3. Tujuh produk pemanfaatan bambu pada lahan masyarakat di Desa Kading, Kabupaten Barru: a). kurungan ayam, b).dinding, c). baki ayam, d). rebung, e). alat pengering ikan, f).bubu ikan (alat penangkap ikan), dan g). lemang.

Pada luasan ketiga $(0,21-0,28 \mathrm{ha})$ adalah luasan yang memiliki rumpun bambu terkecil (72 rumpun), namun rata-rata petani memiliki jumlah bambu muda (181 batang), bambu tua (211 batang) dan rata-rata jumlah bambu yaitu 51 , lebih banyak dibandingkan pada kedua lahan lainnya. Adapun potensi rata-rata rebung terbanyak yang dimiliki oleh petani adalah 98 buah yakni pada lahan luasan 0,29-0,36 ha.

Tabel 5. Juga menunjukkan bahwa semakin luas lahan masyarakat maka, semakin banyak jumlah rumpun yang tumbuh pada lahan tersebut. Namun tidak mempengaruhi tingkat pertumbuhan batang (bambu muda, bambu tua) di setiap rumpun karena pada umumnya bambu yang tumbuh pada lahan masyarakat hanya tumbuh pada pinggiran lahan.

\section{Potensi Rumpun Per Hektar}

Luas total lahan masyarakat yang ditumbuhi bambu di Desa Kadding adalah 7,29 ha dengan jumlah 250 rumpun, Jika dirata-ratakan, maka per hektar lahan ditumbuhi 34 rumpun bambu. Penelitian yang dilakukan oleh Baharuddin, Sanusi, Putranto, \& Daud (2015) menunjukkan potensi rumpun bambu di Kecamatan Tanralili, Kabupaten Maros sebanyak 192 rumpun per ha. Sedangkan penelitian yang dilakukan oleh Muin et al. (2006) di Maros memperoleh hasil jumlah batang per hektar adalah 7661, jumlah batang per rumpun sebesar 47 batang dan jumlah rumpun sebesar 163 per ha. Jika dibandingkan dengan dua penelitian ini, maka jumlah bambu yang berada di Desa Kading jauh lebih rendah. Jika setiap hektar ditumbuhi 34 rumpun bambu, maka pada luasan lahan masyarakat keseluruhan seluas 7,29 ha dapat mencapai 247 rumpun bambu.

\section{Pemanfaatan Tanaman Bambu}

Bambu merupakan jenis tanaman yang dikenal luas oleh masyarakat Indonesia pada umumnya dan masyarakat Sulawesi Selatan pada khususnya. Bambu sudah dimanfaatkan oleh masyarakat secara luas dalam setiap aspek kehidupan, baik dari aspek ekonomi, ekologi, dan sosial budaya. Upacara-upacara keagamaan, perkawinan, kelahiran, kematian dan kegiatan kebudayaan lainnya, tidak terlepas dari pemanfaatan bambu. Bambu dapat dikatakan sebagai tanaman serbaguna karena hampir semua bagian tanaman dapat dimanfaatkan, seperti akar, tunas, ranting dan batang bambu. Selama ini, bambu banyak dimanfaatkan, misalnya sebagai bahan konstruksi, kerajinan, alat musik, serta industri pulp dan kertas.

Pemanfaatan bagian bambu yang banyak digunakan pada lahan masyarakat di Desa Kading adalah batang bambu, bentuk bahan baku yang digunakan pada umumnya adalah batang bambu dalam bentuk belah, bambu bulat atau gabungan dari keduanya. Produk bambu yang khusus dimanfaatkan dan atau dijual langsung oleh Petani bambu di Desa Kading, Barru ditunjukkan pada Tabel 6. 
Masyarakat di Desa Kading sudah memanfaatkan semua kelas bambu. Namun, penggunaan bambu tua lebih dominan dibandingkan penggunaan bambu muda. Aneka produk pemanfaatan bambu di Desa Kading ditunjukkan pada Gambar 3. Umumnya bambu yang digunakan untuk pembuatan pagar, bubu ikan, serta bahan konstruksi (dalam bentuk batangan) adalah bambu tua. Bambu muda hanya digunakan pada pembuatan lemang, sedangkan rebung khusus untuk dijadikan bahan makanan (sayur). Setiap produk menggunakan bambu dalam jumlah yang berbeda. Misalnya dalam pembuatan baki ayam dibutuhkan satu batang bambu tua. Sedangkan dalam pembuatan bubu ikan dibutuhkan dua batang bambu tua.

\section{E. KESIMPULAN}

Potensi bambu yang ada di Desa Kading dari 30 responden yaitu 250 rumpun bambu, terdiri atas 2.203 rebung, 5.345 bambu muda, dan 4.532 bambu tua. Setiap rumpun, rata-rata berpotensi memiliki 9 rebung, 21 bambu muda dan 18 bambu tua. Masyarakat Desa Kading sudah memanfaatkan semua kelas bambu (rebung, bambu muda, bambu tua) untuk pembuatan pagar, baki ayam, kurungan ayam, bubu ikan dan dinding serta alat pengering ikan. Produk bambu yang dihasilkan oleh pengrajin bambu yang ada di Desa Kading belum mampu meningkatkan kesejahteraan pengrajin karena, masyarakat Desa Kading hanya mampu membuat sebuah produk yang tidak bernilai tinggi di pasaran, disamping itu masyarakat tidak menjadikan pengolahan bambu sebagai pekerjaan tetap untuk memenuhi kehidupan sehariharinya.

\section{DAFTAR PUSTAKA}

Baharuddin, Sanusi, D., Putranto, B., \& Daud, M. (2015). Analisis Pendapatan Petani Hutan Bambu Rakyat di Kecamatan Tanralili, Kabupaten Maros. MATOA: Jurnal IImu Kehutanan, 3(5), 1-15. $\quad$ Retrieved from https://www.researchgate.net/publication/327535332
[BPS] Badan Pusat Statistik Kabupaten Barru. (2017). Barru Regency In Figures. Barru.

Daud, M., Achmad, N., Faisal, M., \& Baharuddin. (2016). Pemetaan Potensi Hasil Hutan Bukan Kayu Sebagai Bahan Bangunan Lokal Di Provinsi Sulawesi Selatan. Seminar Teknis Pusat Penelitian Dan Pengembangan Perumahan/Balai Litbang Teknologi Permukiman Tradisional Wilayah Makassar, (December). Retrieved from https://www.researchgate.net/publication/327424412

Hamim, A. R., Zaidon, A., Abdood, F., \& Anwar, U. (2010). Adhesion and Bonding Characteristic of Preservatif-Treated Bamboo (Gigantochloa scortechinii) Laminates. Journal of Applied Sciences, 10(14), 1435-1441.

Hingmadi, D. (2012). Keanekaragaman Ciri Morfologi Jenis-Jenis Bambu (Bambusa Sp.) Di Kelurahan Teunbaun Kecamatan Amarasi Barat Kabupaten Kupang. Universitas PGRI NTT, Kupang.

Lempang, M. (2016). Pengawetan Bambu Untuk Barang Kerajinan Dan Mebel Dengan Metode Tangki Terbuka. Info Teknis EBONI, 13(2), 79-92.

Mahendra, A. D. (2014). Analisis Pengaruh Pendidikan, Upah, Jenis Kelamin, Usia Dan Pengalaman Kerja Terhadap Produktivitas Tenaga Kerja (Studi di Industri Kecil Tempe di Kota Semarang). Universitas Diponogoro, Semarang.

Muin, M., Suhasman, Oka, N. P., Putranto, B., Baharuddin, \& Millang, S. (2006). Pengembangan Potensi dan Pemanfaatan Bambu sebagai Bahan Baku Konstruksi dan Industri di Sulawesi Selatan (Edisi Pert; I. Madjid, Ed.). Ujung Padang: Badan Penelitian dan Pengembangan Daerah (Balitbangda) Propinsi Sulawesi Selatan.

Priyanto, \& Abdulah, L. (2014). Identifikasi dan Zonasi Kawasan Untuk Pengembangan Industri Bambu Di Bali. Bogor.

Sutardi, S. R., Nadjib, N., Muslich, M., Jasni, Sulastiningsih, I. ., Komaryati, S., ... Basri, E. (2015). Seri Paket Iptek Informasi Sifat Dasar dan Kemungkinan Penggunaan 10 Jenis Bambu. Bogor: Pusat Penelitian dan Pengembangan Hasil Hutan; Badan Penelitian, Pengembangan dan Inovasi; Kementerian Lingkungan Hidup dan Kehutanan.

Tanto, D., Dewi, S. M., \& Budio, S. P. (2012). Faktor-Faktor yang Mempengaruhi Produktivitas Pekerja pada Pengerjaan Atap Baja Ringan di Perumahan Green Hills Malang. Jurnal Rekayasa Sipil, 6(1), 69-82. 